\title{
Characteristics and composition of the falling dust in urban environment
}

\author{
M. AL-Harbi
}

Received: 22 June 2012/Revised: 22 May 2013/Accepted: 20 November 2013/Published online: 18 December 2013

(C) Islamic Azad University (IAU) 2013

\begin{abstract}
The monthly total amount of dust fall, as well as its chemical and physical characteristics, was systematically investigated in Shuwaikh city, Kuwait. Dust samples were collected on a monthly basis for the entire year of 2009 and analyzed in the laboratory for water-soluble and water-insoluble matter. Water-insoluble matter represented the major portion of the total annual dust. ANOVAs showed significant temporal variation in the concentration of dust fall over the months $(p<0.05)$. Higher dust deposits were encountered between June and August and ranged from 76.4 to $97.6 \pm 2.5(\mathrm{SD})$ ton $\mathrm{km}^{-2}$ month ${ }^{-1}$, where dusty winds and low humidity are a common attribute in such arid areas. The main three soluble matter species measured are nitrate, sulfate, and chloride, and sulfate was found to be the most abundant inorganic species, ranging from $0.72 \pm 0.13$ to $4.1 \pm 0.3$ ton $\mathrm{km}^{-2}$ month ${ }^{-1}$. Major insoluble matter species measured are ash, silica, combustible, and tarry. Ash, silica, and combustible account for 63,19 , and $17.8 \%$ of total insoluble dust, and $58.4,17.7$, and $16.6 \%$ of total dust, respectively. Particle size distribution was also investigated, and results showed that dust particles $>7 \mu \mathrm{m}$ were the highest concentration of falling dust. Metrological conditions were found to play a vital role in temporal variations in falling dust.
\end{abstract}

Keywords Dust fall $\cdot$ Seasonal variation $\cdot$ Water-soluble and water-insoluble matter

M. AL-Harbi $(\square)$

Department of Environmental Technology Management,

College of Life Sciences, Kuwait University, P.O. Box 5969,

13060 Safat, Kuwait, Kuwait

e-mail: dr.meshari@ku.edu.kw

\section{Introduction}

Dust storms are one of the most noticeable environmental phenomena in arid and semi-arid regions. Kuwait is located in an arid and semi-arid region, and it is within one of the five major regions where dust originates (Modaihsh 1997). Consequently, dust has been a common natural phenomenon in this area. Dust storms arise when a gust front or other strong wind blows loose sand and dirt from a dry surface. Dust storms have significant influence on global geochemical mass cycles, atmospheric radiation transfer, marine ecosystem, and human health (Gao et al. 1997; Yang 2005; Wang et al. 2005). In recent years, the effects of particles on human health are of greatest concern in urban areas. Epidemiological studies revealed relationships between fine particle concentration and both respiratory and cardiovascular diseases (Pope 2000; Samet et al. 2000). Numerous studies have reported that the adverse health effects caused by concentrations of ultrafine particles are stronger than those created by the mass concentration of the fine particles (Peters et al. 1997; Penttinen et al. 2001). Dust storms can affect climate directly by scattering and absorbing solar radiation (Charlson et al. 1992). Additionally, coagulation and condensation of pollutants on dust particles during transport can further complicate the problem by changing their optical properties (Chou et al. 2003). It was strongly shown that dust particles can react with pollution gases such as $\mathrm{SO}_{2}$ and $\mathrm{NO}_{\mathrm{X}}$ or pollution aerosol by gas/particle interactions during transport, which may alter the nitrogen and sulfur cycles, as well as the acid/base balance (Parungo et al. 1996; Iwasaka et al. 2003; Chung et al. 2003; Li and Shao 2009).

Several studies have investigated the compositions of falling dust. Okada et al. (1990) reported that individual Asian dust particles collected over Japanese islands sometimes had an internal mixture of water-soluble and water-insoluble material, and the water-soluble material mainly contained $\mathrm{Ca}$ and $\mathrm{S}$. 
Krueger et al. (2004) also found high yields of nitrate formation on calcite and dolomite among individual dust particles from different dust source regions. Traffic and coal burning, accountable for the high levels of $\mathrm{NO}_{\mathrm{x}}$ and $\mathrm{SO}_{2}$, are also the main producers of soil and coal ash mineral particles (Hien et al. 2001, 2004; Begum et al. 2004; Gwilliam et al. 2004). Previous comparative studies of dust particles collected in China and Japan during similar dust storm episodes show that sea salt and sulfur accumulate on dust particles during the transportation from China to Japan (Zhou et al. 1994; Fan et al. 1996). Zhang et al. (2003) studied the mixture of Asian dust particles collected in southwestern Japan in the spring of 2000 by SEMEDX. They found that mineral materials could enhance particulate sulfate and nitrate formation and restrain chlorine depletion from the sea salt components in mixture particles. $\mathrm{Li}$ et al. (2011) has recently investigated aerosol particles collected at a high-elevation mountain site in the North China plain (NCP) during April 2010. The study revealed that sulfate particles can coagulate with dust particles through the physical movement (long-range transport). Additionally, the authors reported the heterogeneous reactions between dust particles and $\mathrm{SO}_{2} / \mathrm{NO}_{2}$ or their acids, which could result in internally mixed particles. In urban cities, organic compounds are the major constituents of dust after sulfate and nitrates. Tarry matter represents the total organic matter in ambient carbonaceous aerosols, while combustible or unburnt hydrocarbons are a measure of non-volatile compounds in the atmospheric aerosols (Lighty et al. 2000; Johansson et al. 2003).

Particle size distribution measurements have been taken in several European and US cities, e.g., Birmingham (Harrison et al. 1999), Atlanta (Woo et al. 2001), Helsinki (Hussein et al. 2004), Leipzig (Wehner and Wiedensohler 2003), Pittsburgh (Stanier et al. 2004). In terms of seasonal variations, particle number concentrations were slightly lower in summer and higher in winter (Wehner and Wiedensohler 2003; Hussein et al. 2004). In the context of diurnal patterns, particle number concentrations were found to be strongly influenced by the traffic density in the urban area (Tuch et al. 2003; Wehner and Wiedensohler 2003; Hussein et al. 2004; Stanier et al. 2004). Substantial increases of particle number concentration, especially the Aitken mode particles, were observed during traffic peak hours (e.g., Shi and Harrison 1999). Thus, traffic emissions were considered to be one of the most important sources of particles in the urban atmosphere. Tang and Wang (2006) investigated vehicle gaseous emissions ( $\mathrm{NO}, \mathrm{CO}, \mathrm{CO}_{2}$, and $\mathrm{HC})$ and driver's particle exposures $\left(\mathrm{PM}_{1}, \mathrm{PM}_{2.5}\right.$, and $\left.\mathrm{PM}_{10}\right)$ under very heavy traffic in the urban hot spots in Macao. The measurements were carried out in close proximity to the vehicles, and the inlets of the particle analyzers were positioned at the height of the driver's breathing point. Results showed that motorcycles were higher contributor of particle exposures compared with passenger cars for petrol vehicles, while trucks and buses resulted in higher particle exposures compared with taxis for diesel vehicles. The authors ascribed that to both poor maintenance and the incompetent combustion of fuel or lubricant in motorcycles. Similar trends were also observed in California vehicles (Fruin et al. 2004), New York vehicles (Canagaratna et al. 2004), and Denmark vehicles (Ntziachristos et al. 2000). Tang and Wang (2007) studied the impact of different urban forms, existing currently on the Macao Peninsula, on vehicle transport and street environment using various modeling systems. Results revealed that urban forms 1 and 2, which are characterized with a high percentage $(>48.7 \%)$ of narrow roads ( $\leq 10 \mathrm{~m}$ wide), high density of intersections, and complex road network, restrict the traffic and parking capacities and thus result in reduction in passenger car and motorcycle volumes. This reduction in traffic volumes led to lower noise pollution. With regard to $\mathrm{CO}$ emission, the greater street canyon effects in urban forms 1 and 2 resulted in higher CO concentrations. In recent study (Li et al. 2011), it was suggested that dust particles may absorb the acidic gases during the long-range transport and scavenge the fine particles, which ultimately reduce the particle and particle number concentrations and grown particle size.

The impact of meteorological parameters, such as wind speed, wind direction, solar radiation, and precipitation, on the dust constituents and size distributions has gain a least attention in the literature. In one study (Väkevä et al. 2000), it was found that the wind direction weighs heavily in shaping particle number size distributions in the urban background area of Helsinki, Finland. Other studies have reported that long-range transport also plays a vital role in changing the particle number concentrations (Tiitta et al. 2002; Niemi et al. 2004).

Several studies focused on measurement of falling dust included identifying its physical, chemical, and size distribution. Most, if not all, previous studies were conducted in developed countries, with only few observations in Asian countries, including India, Beijing, Korea, and Taiwan. To the author's knowledge, none of these detailed studies were conducted in Middle East countries, which are located in major regions where dust originates. Therefore, the current paper is aimed to systematically study the chemical and physical characteristics of falling dust in Kuwait. Moreover, the relationship between the nature of falling dust and metrological conditions is statistically investigated.

\section{Materials and methods}

Site location and sampling method

Dust particles were collected on a monthly basis for the entire year of 2009 in Shuwaikh city, Kuwait. This area (coordinates $29^{\circ} 21^{\prime} 9^{\prime \prime} \mathrm{N} 47^{\circ} 55^{\prime} 31^{\prime \prime} \mathrm{E}$ ) is partly industrial and partly rural. It contains several businesses, including car mechanics, car dealerships, and furniture stores. The Kuwait University 
Campus, as well as residential houses, is also located in this area. Therefore, the observation site was quite interesting regarding the measurements of falling dust. Dust fall was collected using open plastic buckets filled with distilled water. These buckets were placed about $3 \mathrm{~m}$ above the ground and exposed to the atmosphere for 1 month. All analyses were conducted in duplicate, and each value measured is a mean of at least three replicate determinations. Data on dust fall and its constituents are expressed in ton $\mathrm{km}^{-2}$ month ${ }^{-1}$.

Dust fall determination and chemical analysis

Collected dust samples at monthly intervals are analyzed in the laboratory. Insoluble matter, soluble matter, and ash were determined gravimetrically (Lodge 1988). Briefly, all collected samples were filtered using Whatman glass microfiber filters $(\mathrm{GF} / \mathrm{C})$ to determine the composition of insoluble matter. Subsequently, the filter paper was dried in an oven at $108{ }^{\circ} \mathrm{C}$ for $2.5 \mathrm{~h}$, and afterward kept in a desiccator prior being weighed at least three replicates until the weight of filter paper and insoluble materials became constant. Insoluble matter concentration was quantified using the method by Norela et al. (2009), which is based on the weight differences of filter papers, the area of the dust fall container opening mouth, and number of days (in 1 month); as Eq. (1):

Concentration of insoluble matter $\left(\mathrm{g} / \mathrm{m}^{2} /\right.$ day $)$

$$
=\frac{\left(W_{f}-W_{i}\right)}{A T}
$$

where $W_{i}$, weight of the filter without sample $(\mathrm{g}) ; W_{f}$, weight of the filter with dry insoluble solids after filtration (g); $A$, area of dust fall container opening mouth $\left(\mathrm{m}^{2}\right) ; T$, period of sampling days (days).

For the estimation of soluble matter concentration, the collected samples were placed on the preweighed evaporating dish and then dried in the oven at $108{ }^{\circ} \mathrm{C}$ for $2.5 \mathrm{~h}$ and subsequently cooled in a desiccator before being weighed. Soluble matter concentration was quantified using the method followed by Latif and Rozali (1991), which is based on the weights differences of the evaporating dish (before and after the drying of the sample), the ratio between volume of water collected and the water used for analysis, the area of the dust fall container opening mouth, and the number of days (in 1 month); as Eq. (2):

Concentration of soluble matter $\left(\mathrm{g} / \mathrm{m}^{2} /\right.$ day $)$

$$
=\frac{\left[\left(W_{f}-W_{i}\right)\left(\frac{V_{1}}{V_{2}}\right)\right]}{A T}
$$

where $W_{i}$, weight of empty evaporating dish (g); $W_{f}$, weight of the evaporating dish with soluble matter $(\mathrm{g}) ; A$, area of dust fall container opening mouth $\left(\mathrm{m}^{2}\right)$; $T$, period of sampling days (days); $V_{1}$, volume of liquid transported to the laboratory $(\mathrm{L})$; $V_{2}$, volume of liquid dispensed into the crucible (L).
Total dust deposition was calculated as the sum of insoluble and soluble matter. Tarry matter is an organic matter that has the characteristic of tar or pitch. Tarry content in the waterinsoluble matter was determined via acetone extraction. The acetone residue weight represents the tarry matter content. Ash defined as a powdery residue of matter that remains after burning. To determine the ash content, the extracted insoluble matter was then heated in an oven at $850{ }^{\circ} \mathrm{C}$. The residue matter was the ash content, while combustible matter was obtained as the difference between insoluble matter and ash.

Silica contents were determined using FT-IR spectrophotometer (model 510P). The spectrophotometers were checked for malfunctioning by passing standard solutions of all the parameters to be measured; blank samples were passed between measurements to check for any eventual contamination or abnormal response of equipment. Nitrate, sulfate, and chloride contents were analyzed using ion chromatography (DIONEX-600).

Dust particle size

Dust particle size distributions were measured using Andersen hi-vol fractionating samplers (Model 65-000, Andersen 2000, Inc., Atlanta, GA, USA). These consist of a series of 30-cm-diameter (12 in.) aluminum plates with holes offset from the plates and filters in succession. They were designed for placement on the top of an ordinary hivol sampler (GMW 2000H, General Metal Works, Cleves, $\mathrm{OH}$, USA) and were operated at the recommended flow rate of $0.57 \mathrm{~m}^{3} \mathrm{~min}^{-1}(20 \mathrm{cfm})$.

Dust samples were collected in five separate aerodynamic size ranges as follows: 0.01-1.1 $\mu \mathrm{m}$ (backup), 1.1-2.0 $\mu \mathrm{m}$, 2.0-3.3 $\mu \mathrm{m}, 3.3-7.0 \mu \mathrm{m}$, and larger than $7.0 \mu \mathrm{m}$. The four upper stages use perforated, circular, Gelman Type A glass fiber filters, as supplied commercially (Andersen 2000, Inc., Atlanta, GA, USA). The backup filter was $20 \times 25 \mathrm{~cm}$ $(8 \times 10$ in.). Gelman Spectro Grade filters were used throughout the present study.

\section{Results and discussion}

\section{Metrological conditions}

Temporal variations in meteorological parameters such as wind speed $\left(\mathrm{m} \mathrm{s}^{-1}\right)$, precipitation $(\mathrm{mm})$, temperature $\left({ }^{\circ} \mathrm{C}\right)$, and relative humidity $(\%)$ during the study period are shown in Fig. 1a, b. The most frequent meteorological parameters determining the horizontal transport and dispersion of air particles are the mean wind speed and the wind direction (Ziomas et al. 1995). The average monthly wind speed was $4.4 \mathrm{~m} \mathrm{~s}^{-1}$, with values ranging from 2.9 to $6 \mathrm{~m} \mathrm{~s}^{-1}$. Northwesterly winds were the most predominant throughout the year, but more so in 
Fig. 1 Temporal variations in monthly average dust fall and metrological parameters
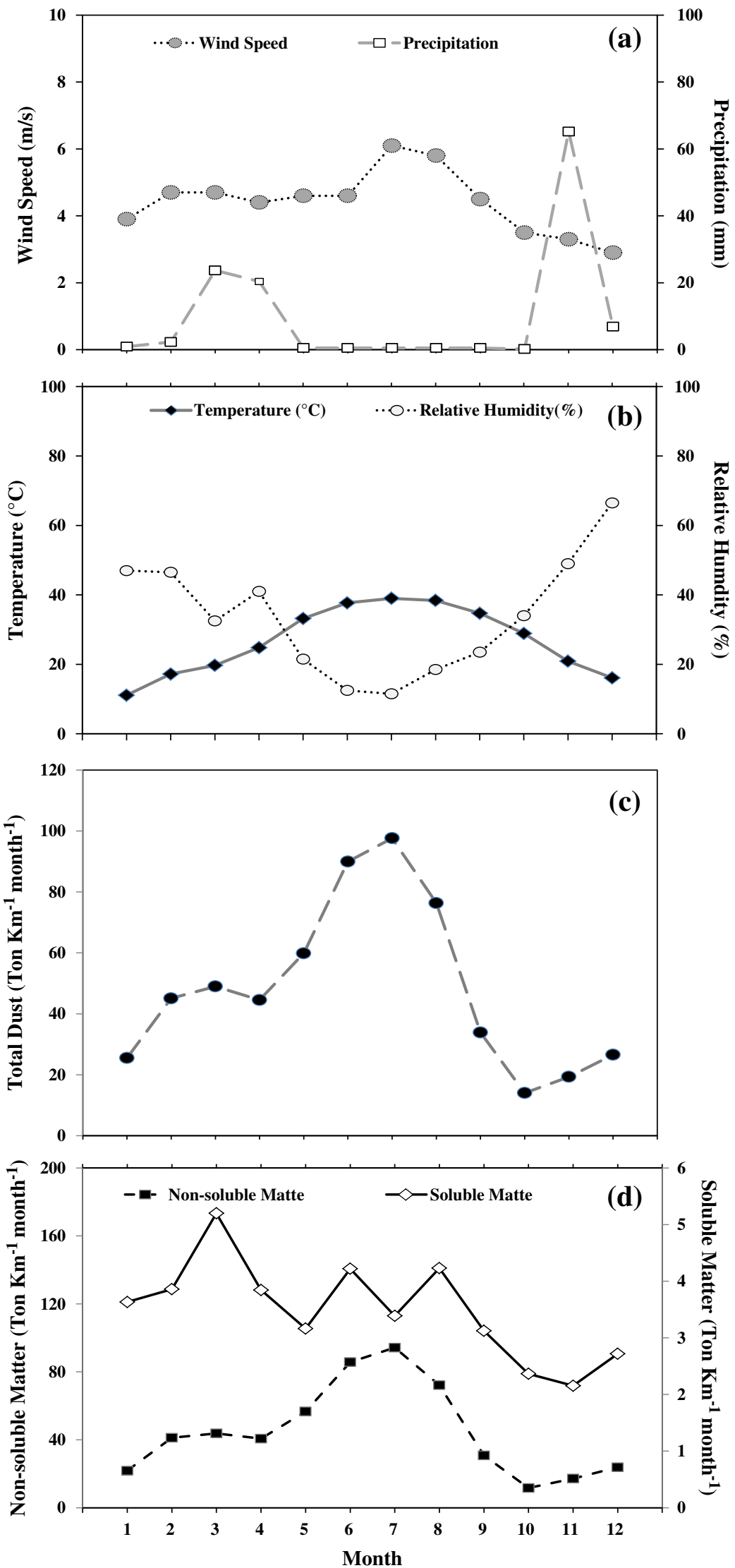
the months of June-August. After northwesterly winds, the most common were southeasterly, which were experienced more often from February to April. This area received approximately $122 \mathrm{~mm}$ of rainfall (precipitation) in the year of 2009 (study time), and $53 \%(65.2 \mathrm{~mm}$ ) of the total rainfall was during the month of November. The average monthly relative humidity was $33.7 \%$, with values ranging from 11.5 to $66.5 \%$ during the investigated period. The maximum relative humidity records were obtained between November and December, while minimum records attained were in June and July. The average temperatures ranged from 11 to $28^{\circ} \mathrm{C}$ between October and January, $17-33{ }^{\circ} \mathrm{C}$ between February and May, and $35-39^{\circ} \mathrm{C}$ between June and September.

Seasonal variations in dust fall

Figure 1c shows the average monthly variation in the dust fall during the period of June through December 2009. The analysis of variance (ANOVA) showed significant temporal variation in the concentration of dust fall over the months $(p<0.05)$. Highest levels of dust deposits were observed between June and August and ranged from 76.4 to $97.6 \pm 2.5$ (SD) ton $\mathrm{km}^{-2}$ month $^{-1}$, where these months are characterized by dusty winds and low humidity in such arid areas. Additionally, the dust levels rose further by surface erosion and dust resuspension due to prolonged high winds (up to $6 \mathrm{~m} \mathrm{~s}^{-1}$ ) and thermal turbulence caused by high temperatures. Minimum dust deposits were observed during October and November and ranged from $14 \pm 1.2$ to 19. \pm 1.4 ton $\mathrm{km}^{-2}$ month $^{-1}$. These lowest valuesare attributed to heavy rainfall during these months, in which it washed out the dust. Falling rain captures aerosol particles via inertial impaction, diffusiophoresis, Brownian and turbulent shear diffusion, thermophoresis, and electric charge effects (Chate and Pranesha 2004). Intermediate values were observed in the months of December, January, and February, with a range of $25.5 \pm 1.3-30.5 \pm 1.5$ ton $\mathrm{km}^{-2}$ month $^{-1}$, which could be ascribed to climatic inversions, as well as constantly changing wind speeds and directions (Lyons and Scott 1990).

\section{Chemical constituents of dust fall}

All monthly average measurements of dust-soluble and dustinsoluble matters during the year of 2009 are shown in Fig. 1d. It is evident from Fig. 1d that the water-insoluble matter was comparatively higher (range $11.7 \pm 1.9-94 \pm 2.1$ ton $\mathrm{km}^{-2}$ month $^{-1}$ ) than the water-soluble matter (range $2.16 \pm 0.5-5.2 \pm 0.55$ ton $\mathrm{km}^{-2}$ month ${ }^{-1}$ ) over all tested periods. The coefficient of variation $(\mathrm{CV})$ of water-insoluble matter was relatively high $(\mathrm{CV}=0.6)$ compared with watersoluble matter $(\mathrm{CV}=0.25)$ over all tested periods, for the same reasons mentioned in previous sections.

Temporal variation and distribution of chemical components of dust fall, as well as soluble and insoluble matter during the tested period, are shown in Figs. 2 and 3. Descriptive statistics of chemical components of dust fall during the tested period are also shown in Table 1. The main three soluble matter species measured are nitrate, sulfate, and chloride, while the major insoluble matter species measured are ash, silica, combustible, and tarry.

In dust-soluble matter, sulfate was found to be the most abundant inorganic species. The sulfate amount ranged from $0.72 \pm 0.13$ to $4.1 \pm 0.3$ ton $\mathrm{km}^{-2}$ month $^{-1}$ (average $2.37 \pm 0.2$ ton $\mathrm{km}^{-2}$ month $^{-1}$ ) and accounted for 5 and $68 \%$ of the total dust fall and its soluble matter, respectively, during the year of 2009. Another major soluble species is chloride, one of the sea salt's aerosol components. The chloride concentrations ranged from $0.165 \pm 0.1$ to $0.383 \pm 0.11$ ton $\mathrm{km}^{-2}$ month ${ }^{-1}$ (average 0.257 ton $\mathrm{km}^{-2}$ month $^{-1}$ ) and were 0.52 and $7.5 \%$ of the total dust fall and its soluble matter, respectively, during the year of 2009. No significant fluctuations were observed for chloride with respect to month (Tripathi et al. 1991). Nitratewas found to have low concentrations among water-soluble components. The maximum amount detected was $0.012 \pm 0.001$ ton $\mathrm{km}^{-2}$ month ${ }^{-1}$, with an average of 0.004 ton $\mathrm{km}^{-2}$ month ${ }^{-1}$. On average, three major anthropogenic soluble matter species (sulfate, chloride, and nitrate) accounted for 5.52 and $75.5 \%$ of the total dust fall and its soluble matter, respectively, during the year of 2009.

Among dust-insoluble species, the ash content of dust was highest, ranging from $7.81 \pm 0.7$ to $57.82 \pm 0.92$ ton $\mathrm{km}^{-2}$ month ${ }^{-1}$, with an average of 28.327 ton $\mathrm{km}^{-2}$ month $^{-1}$. The maximum amount was observed in the summer, due to dusty winds having a favorable direction. As for the tracers of soil/dust (Maxwell-Meier et al. 2004), silica were frequently observed in higher concentrations, ranging from $1.39 \pm 0.2$ to $25.136 \pm 0.3$ ton $\mathrm{km}^{-2}$ month $^{-1}$, and with an average of 8.613 ton $\mathrm{km}^{-2}$ month ${ }^{-1}$. Significant variations $(\mathrm{CV}=0.97)$ were observed in the amount of silica per month. The combustible fraction of insoluble matter also showed higher values, with an average of $8.03 \pm 0.4$ ton $\mathrm{km}^{-2}$ month ${ }^{-1}$ and with an intermediate variation per month $(\mathrm{CV}=0.51)$. Tarry matter deposition was the lowest (average $=0.011 \pm 0.009$ ton $\mathrm{km}^{-2}$ month $^{-1}$ ) among the insoluble matter. It was in the greatest amount in winter $(0.022 \pm 0.007)$ and relatively lower in the summer months because of the high frequency of ground inversions in winter and high wind velocity in summer. Overall, ash, silica, and combustible account for 63,19 , and $17.8 \%$ of total insoluble dust, and $58.4,17.7$, and $16.6 \%$ of total dust, respectively.

Source of chemical constituents of dust fall

The source of chemical constituents in falling dust and the impact of metrological conditions on the distribution of chemical constituents were also investigated. Table 2 presents the Spearman correlation coefficient matrices between the amount of chemical components of dust fall 


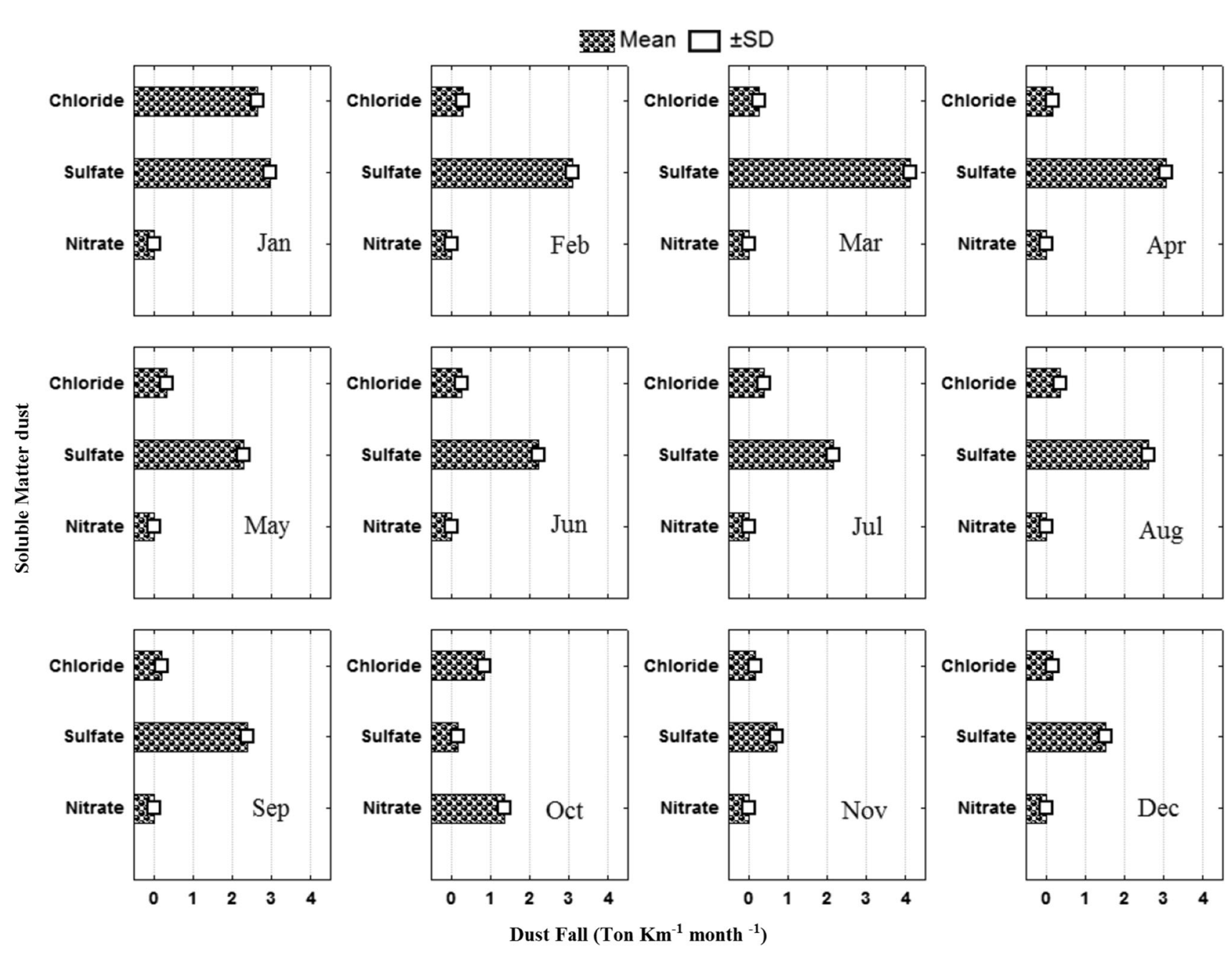

Fig. 2 Temporal variations in monthly average soluble matter in dust fall

and metrological conditions, including wind speed, temperature, relative humidity, and precipitation.

Numerous previous studies have suggested that sulfate and nitrate in dust formed in the atmosphere through homogeneous and heterogeneous reactions (McArdle and Hoffmann 1983; Martin 1984; Hoffmann 1986; Seinfeld 1986; Yang et al. 1991; Quan 1995; Fenter et al. 1995; Zhang 1996; Li and Shao 2009). Heterogeneous reactions involved the transformation of pollution gases, $\mathrm{SO}_{2} / \mathrm{NO}_{\mathrm{X}}$, to sulfate and nitrate, which might take place on the suspended crustal particles remaining in the atmosphere (McArdle and Hoffmann 1983; Martin 1984; Hoffmann 1986). However, heterogeneous conversion is sensitive to relative humidity, and its efficiency decreases with the decrease in humidity. In line with correlation analysis (Table 2), the correlations between sulfate and nitrate concentration and relative humidity were very small, $R=-0.17$ and 0.03 , respectively. The findings diminish the possible that nitrate and sulfate species were formed via heterogeneous reactions between mineral dust particles and acidic gases (e.g., $\mathrm{NO}_{\mathrm{X}}$ and $\mathrm{SO}_{2}$ ). Another possible mechanism of sulfate and nitrate formation is that dust particles absorbed sulfuric and nitric acid (gas or droplets), which were formed through homogeneous reactions of $\mathrm{SO}_{2}, \mathrm{OH}, \mathrm{O}_{2}, \mathrm{H}_{2} \mathrm{O}$; and $\mathrm{NO}_{\mathrm{x}}$ and $\mathrm{OH}$ or $\mathrm{N}_{2} \mathrm{O}_{5}$ and $\mathrm{H}_{2} \mathrm{O}$ occurring in the atmosphere (Seinfeld 1986). Such reactions are independent of the humidity of ambient air (Fenter et al. 1995). This possibility, however, cannot exclude the occurrence of other heterogeneous reactions between mineral dust and aqueous acids once the mineral dust particles absorb the acids. In the tested area, $\mathrm{SO}_{2}$ and $\mathrm{NO}_{\mathrm{x}}\left(\mathrm{NO}\right.$ and $\mathrm{NO}_{2}$ ) emissions are usually high, as it is surrounded by various industries. To further investigate the relationship between the emissions of $\mathrm{SO}_{2}$ and $\mathrm{NO}_{\mathrm{X}}$ per month, as well as dust sulfate and nitrate, $\mathrm{SO}_{2}$ is plotted versus dust sulfate and $\mathrm{NO}_{\mathrm{X}}$ isplotted versus dust nitrate, as shown in Fig. 4a, b. Spearman's correlation analysis showed a significant relationship $(R=0.66$ and $p<0.05)$ between the emission of $\mathrm{SO}_{2}$ and dust sulfate, which could be the precursor of sulfate formation. Conversely, the Spearman correlation coefficient was low between the emissions of $\mathrm{NO}_{\mathrm{X}}$ and dust nitrate. This discrepancy could show that emissions of $\mathrm{NO}_{\mathrm{X}}$ are not merely the source of dust nitrate. 


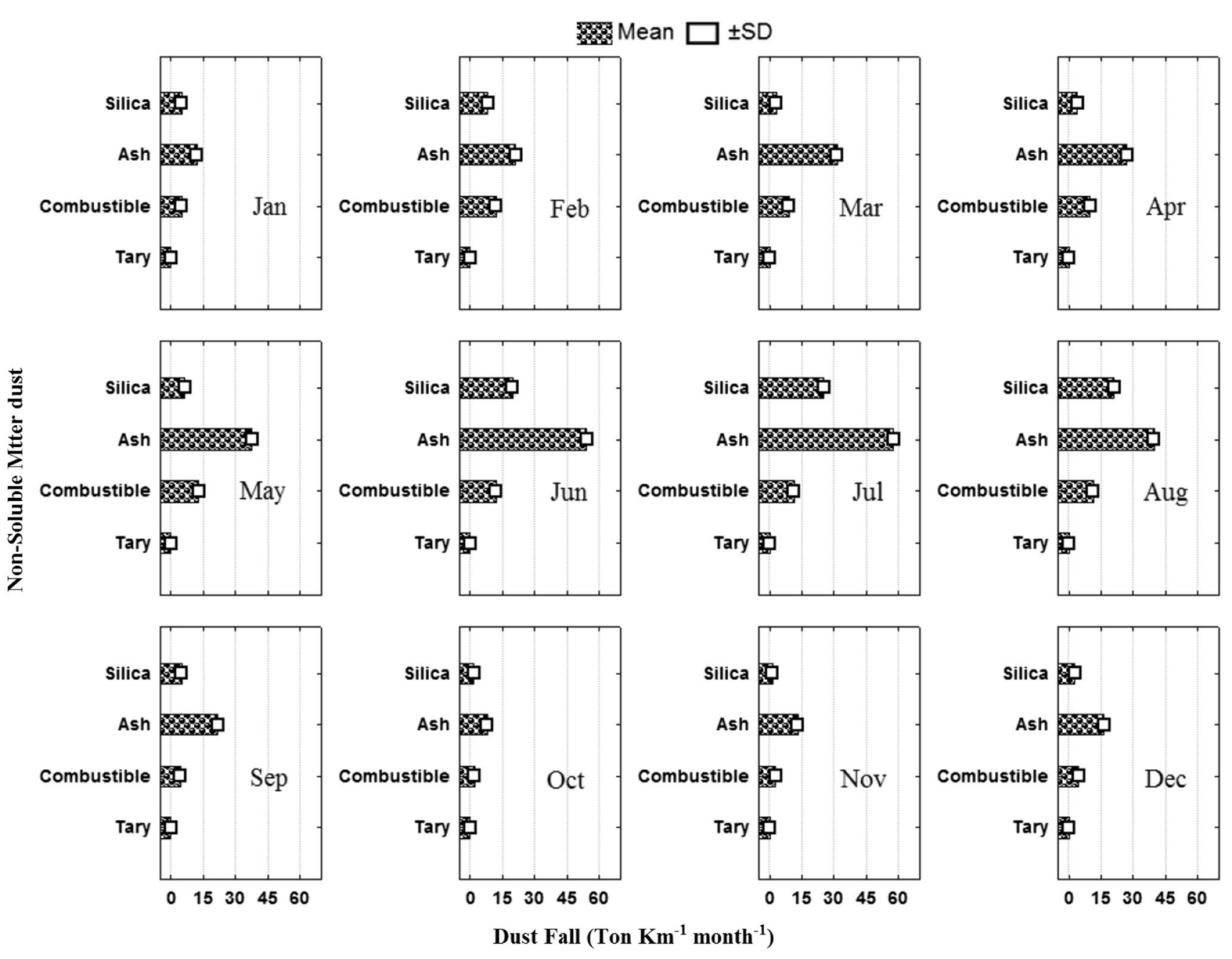

Fig. 3 Temporal variations in monthly average insoluble matter in dust fall

Table 1 Descriptive statistics of dust fall, ton $\mathrm{km}^{-2}$ month $^{-1}$

\begin{tabular}{clccccc}
\hline Solubility & Constituents & Mean & Min. & Max. & SD & CV \\
\hline Soluble & Nitrate & 0.004 & 0.001 & 0.012 & 0.003 & 0.83 \\
matter & Sulfate & 2.374 & 0.724 & 4.111 & 0.91 & 0.38 \\
& Chloride & 0.257 & 0.165 & 0.383 & 0.080 & 0.31 \\
Insoluble & Tarry & 0.011 & 0.000 & 0.022 & 0.008 & 0.72 \\
matter & Combustible & 8.03 & 2.020 & 12.751 & 4.071 & 0.51 \\
& Ash & 28.327 & 7.812 & 57.822 & 16.27 & 0.51 \\
& Silica & 8.613 & 1.391 & 25.136 & 8.35 & 0.97 \\
\hline
\end{tabular}

Previous studies repeatedly reported that the formations of particulate sulfate and nitrate on sea salt particles (Eriksson 1959; McInnes et al. 1994) and dust particles enhanced the production of particulate sulfate and nitrate in the downstream atmosphere (Nishikawa et al. 1991; Dentener 1996; Tang 2004). The sea is about $2-3 \mathrm{~km}$ from the tested area, which is where the particles could have originated from, and the wind could have induced the transportation. Temperature and precipitation showed weak correlation in the formation of either nitrate or sulfate, as shown in Table 2. The quantitative estimation revealed that the chloride amount (Fig. 2) was appreciable compared to the amount of sulfate. Chloride is thought to be primarily derived from sea salt aerosols, especially in a marine environment (Zhuang and Chan 1997). Chloride could deposit onto dust particles through the absorption of chlorine-containing gases or sea salt aerosol when the particles passed through the marine atmosphere. Wind speed can induce such transportation. As shown in Table 2, there wasa significant correlation $(R=0.85$ and $p<0.05$ ) between wind speed and dust chloride.

Silica was found in substantial amount in the falling dust, where it accounted for $19 \%$ of total insoluble dust and $17.7 \%$ of total dust. Silica is more likely to be a product of soil erosion or road dust aerosolized by traffic. Wind speed exhibited a significant correlation with silica $(R=0.73$ and $p<0.05$ ). Higher wind speed also causes greater release of dust particles due to erosion and resuspension. The temperature had a consistent pattern, with relative humidity $(R=0.89$ and $p<0.05)$, and the temperature was inversely 
Table 2 Correlation matrices for selected metrological parameters and dust fall constituents

\begin{tabular}{lcccrrrr}
\hline Parameters & \multicolumn{2}{l}{ Dust fall constituents $\left(\right.$ ton $\left.\mathrm{km}^{-2} \mathrm{month}^{-1}\right)$} & & & \\
\cline { 2 - 7 } & Nitrate & Sulfate & Chloride & Tarry & Combustible & Ash & Silica \\
\hline Wind speed $\left(\mathrm{m} \mathrm{s}^{-1}\right)$ & 0.03 & 0.47 & $\mathbf{0 . 8 5}$ & 0.16 & $\mathbf{0 . 7 4}$ & $\mathbf{0 . 7 9}$ & $\mathbf{0 . 7 3}$ \\
Temperature $\left({ }^{\circ} \mathrm{C}\right)$ & -0.07 & -0.15 & 0.39 & $\mathbf{0 . 6 7}$ & 0.41 & $\mathbf{0 . 7 2}$ & $\mathbf{0 . 6 9}$ \\
RH $(\%)$ & 0.03 & -0.17 & $\mathbf{- 0 . 5 8}$ & -0.44 & -0.53 & $-\mathbf{0 . 7 8}$ & $-\mathbf{0 . 7 1}$ \\
Precipitation $(\mathrm{mm})$ & 0.08 & -0.30 & -0.39 & -0.34 & -0.35 & -0.30 \\
\hline
\end{tabular}

Values denote Spearman's coefficient of correlation $(R)$. Significant correlation $(p<0.05)$ is bolded
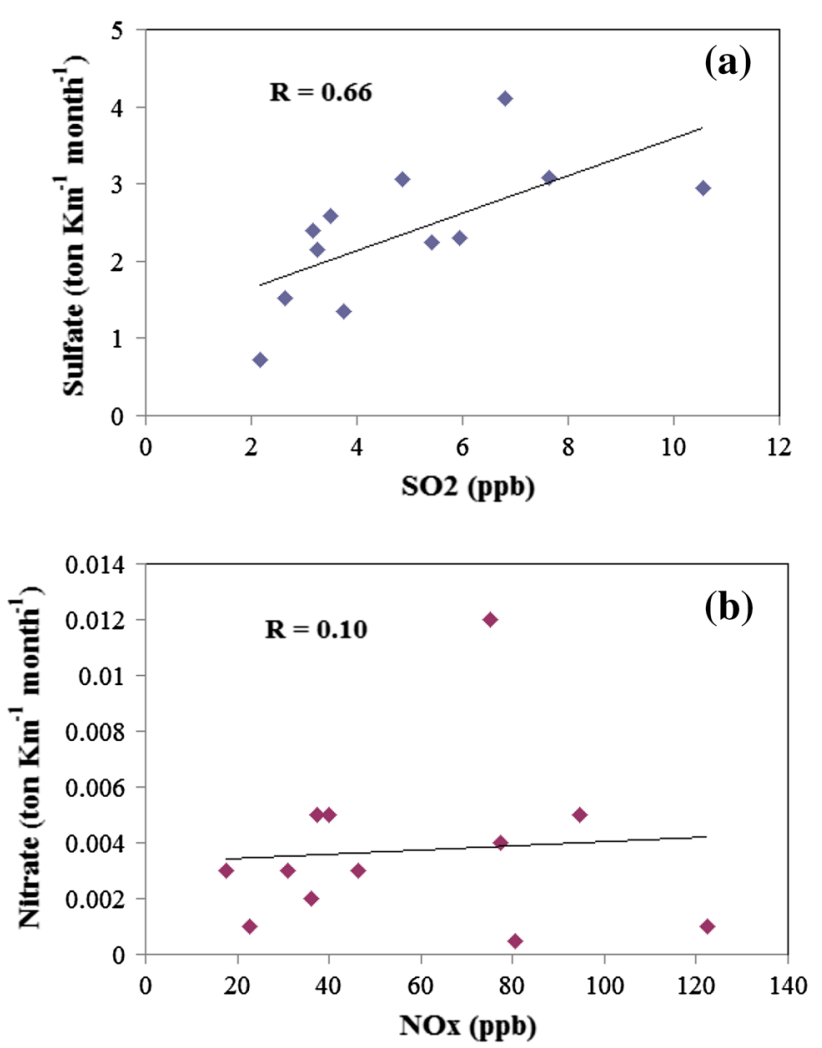

Fig. 4 Correlation analysis between a Sulfate and $\mathrm{SO}_{2}$, b nitrate and $\mathrm{NO}_{\mathrm{X}}$

proportional to relative humidity. Both temperature and relative humidity showed a strong correlation with wind speed, using Spearman's correlation coefficient $(R)$ at 0.65 and 0.78 , respectively. Accordingly, both temperature and relative humidity induced wind speed, which ultimately enhanced the release of dust particles due to erosion and resuspension; this is consistent with the Mirme and $\mathrm{Ru}-$ uskanen (1996) study. The ash content was the highest among the soluble and insoluble matters of the falling dust, with an average of 28.327 ton $\mathrm{km}^{-2}$ month ${ }^{-1}$. The likely source of ash is flying ash from the petroleum industry and a power station, as it is increased in summer, which eliminates the possibility from burning coal from adjacent camping activities. It should be mentioned that the dust collection area was far away from the petroleum industry, but in the close vicinity of a power station. In either case, wind speed was very high in summer, reaching $6.1 \mathrm{~m} \mathrm{~s}^{-1}$. This would, in turn, easily induce the transportation and resuspension of flying ash. A significant correlation was found between wind speed and ash in dust fall $(R=0.79$ and $p<0.05)$. Additionally, both temperature and relative humidity showed a strong correlation with wind speed, as observed with silica. The combustible fraction showed higher values, with an average of $8.03 \pm 0.4$ ton $\mathrm{km}^{-2}$ month $^{-1}$, which accounted for $17.8 \%$ of total insoluble dust and $16.6 \%$ of total dust, respectively. These highest amounts of combustible fractions are the result of frequent running of heavy vehicles and movement of heavy earthmoving machines. Again, strong correlation was found between wind speed and combustible fractions $(R=0.74$ and $p<0.05)$. The temperature and relative humidity had little effect on the amount of combustible fractions.

Tarry matter showed the lowest amount detected among insoluble matter. In contrast to most species, tarry was found in maximum amount during the winter. This finding may increase the possibility that the source of tarry matter in dust could be the products of burning activities from coal burning, petroleum industry, and power station, as these activities are usually increased in winter months. Another possible source of tarry matter is vehicular exhaust (Li et al. 2009; Zheng et al. 1997). The effect of wind speed and relative humidity was insignificant. It should be emphasized that precipitation exhibited slightly low impact on all the constituents of falling dust.

Comparison of dust fall levels with other cities

The average concentrations of dust fall (ton $\mathrm{km}^{-2}$ month $^{-1}$ ) for urban city of Shuwaikh, a central location in Kuwait, was compared with those found in urban areas in other cities (Fig. 5). As shown in Fig. 5, the highest dust fall was found in an opencast coalmine area in Bina of India, with an annual amount of dust fall of 96.2 ton $\mathrm{km}^{-2}$ month ${ }^{-1}$ (Pandey et al. 2008), while the lowest average dust fall was 0.83 ton $\mathrm{km}^{-2}$ month and reported in Southern Nevada (USA), with values ranged between 0.36 and 1.3 ton $\mathrm{km}^{-2}$ month ${ }^{-1}$ (Reheis and Kihl 
1995). The dust fall in Gansu province (China) shows a large annual range of 18.23-69.4 ton $\mathrm{km}^{-2}$ month $^{-1}$ in the desert and Gobi area and 9.7-34.84 ton $\mathrm{km}^{-2}$ month ${ }^{-1}$ in the loess area (Ta et al. 2004). Shuwaikh city (Kuwait), based on this study, followed Bina of India in dust fall with an average amount of 53.7 ton $\mathrm{km}^{-2}$ month ${ }^{-1}$, which is indeed expected as it is located in an arid region, and it is located within one of the five major regions where dust originates. Areas in North and Northwest India exhibited intermediate value $\left(21\right.$ ton $\mathrm{km}^{-2}$ month $^{-1}$ ) of dust fall (Yadav and Rajamani 2006), followed by Nagev desert (Offer and Goossen 2001), Lanzhou (Liu et al. 2004), Texas (Crabtree 2005), Yazd (Naddafi et al. 2006), Arizona (Crabtree 2005), California (Crabtree 2005), and Southern Nevada (Reheis and Kihl 1995), as shown in Fig. 5. The discrepancies of dust fall level among these cities showed that their industrial types and traffic compositions in addition to geographic locations are different from each other. In general, dust fall profile described in Fig. 5 shows that Kuwait is one among the highest urban cities.

\section{Particle size concentration of dust fall}

Temporal variations in dust fall concentration as a function of particle size are shown in Fig. 6, and descriptive statistics are also shown in Table 3. As seen from Fig. 6 and Table 3, dust particle size $>7 \mu \mathrm{m}$ showed the highest concentration of falling dust, which accounted for approximately $44 \%$ of total dust particle sizes. The average concentration of particle size $>7 \mu \mathrm{m}$, as shown in Table 3 , was $263.43 \pm 76.5 \mu \mathrm{g} \mathrm{m}^{-3}$. The concentration of particle size $>7 \mu \mathrm{m}$ was found to be 2 , $2.5,4$, and 7.5 times greater than particle sizes of 0.01-1.1, 3.3-7, 2-3.3, and 1.1-2.2 $\mu \mathrm{m}$, respectively. The concentration of particle size of 0.01-1.1 $\mu \mathrm{m}$ was the second highest, where its average was $115.20 \pm 53.8 \mu \mathrm{g} \mathrm{m}^{-3}$ and accounted for $21.6 \%$ of total dust particle sizes. This observation is consistent with Baik et al. (1996) in Seoul city, where peak concentration was determined at $0.8 \mu \mathrm{m}$. The lowest concentrations $\left(31.62 \pm 12.63 \mu \mathrm{g} \mathrm{m}^{-3}\right)$ detected were for particle size of $1.1-2 \mu \mathrm{m}$, where it accounted for only $6 \%$ of total dust particle sizes.

The impact of metrological conditions on dust fall particle size concentration was also investigated. Spearman's correlation coefficient matrices between metrological conditions and particle size concentration are shown in Table 4. Results in Table 4 present a clear association between the concentration of particle size $<3 \mu \mathrm{m}$ and metrological conditions (wind speed, temperature, and humidity). The concentration of particle size $>3 \mu \mathrm{m}$ is less dependent on metrological conditions, as Spearman's correlation coefficients varies between low and intermediates values.

The likelihood of any particle entering the atmosphere depends upon its size, density, and shape. Additionally, the rate at which particles are deposited from the atmosphere by turbulent deposition can be presented in terms of a deposition velocity, which is a function of the aerodynamic diameter (Nicholson 1988). Meteorological variables affect the initial release of this material and its dispersal once airborne, and the influence increases with decreasing particle sizes. The inert release of material from a surface will be contingent upon the balance between two groups of forces. Bonding forces, such as the electrostatic force if the particle and surface are differently charged or surface tension if the surface is wet, will tend to retain the particle on the surface, as will happen for any physical attachment. Bonding effects are most likely to be affected by the temperature and moisture at the surface that the particle rests on. These conditions will be determined by the temperature and humidity of the surrounding air and by the radiation balance of the surface. Particle size distributions have been studied in numerous cities, e.g., Birmingham (Harrison et al. 1999), Atlanta (Woo et al. 2001), Helsinki (Hussein et al. 2004), Leipzig (Wehner and Wiedensohler

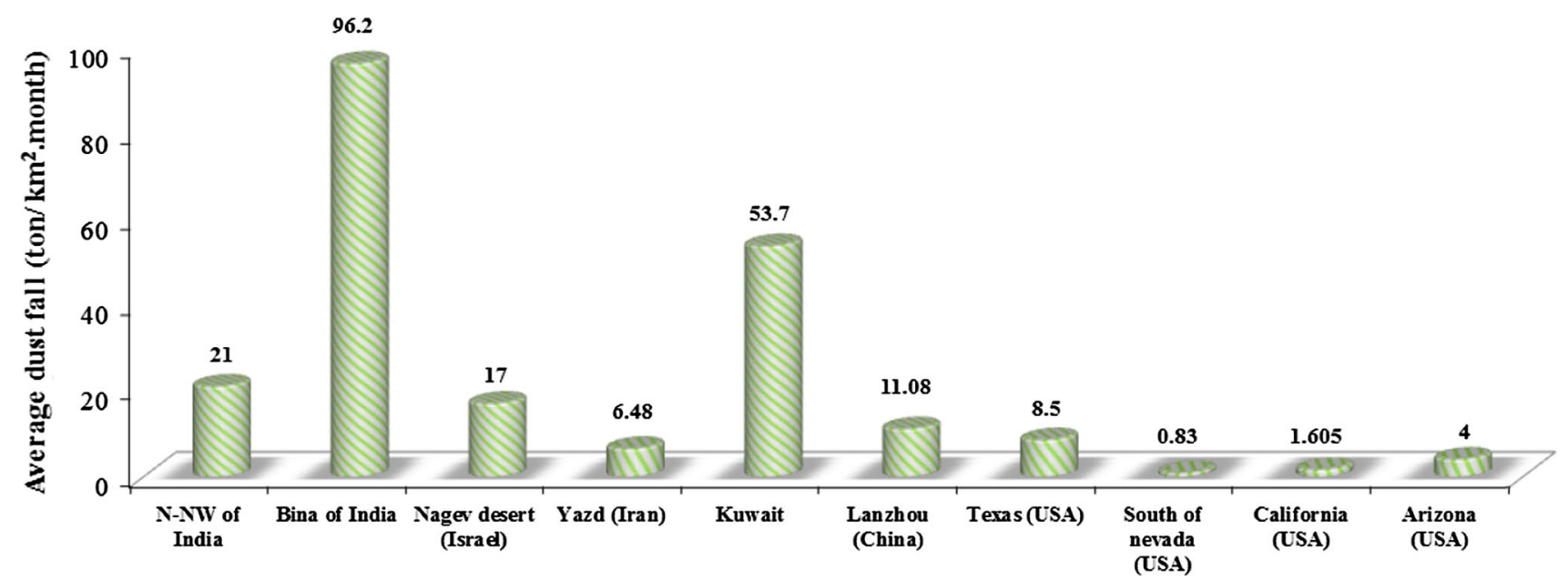

Fig. 5 Comparison of dust fall concentrations for ten cities including Shuwaikh (Kuwait) 


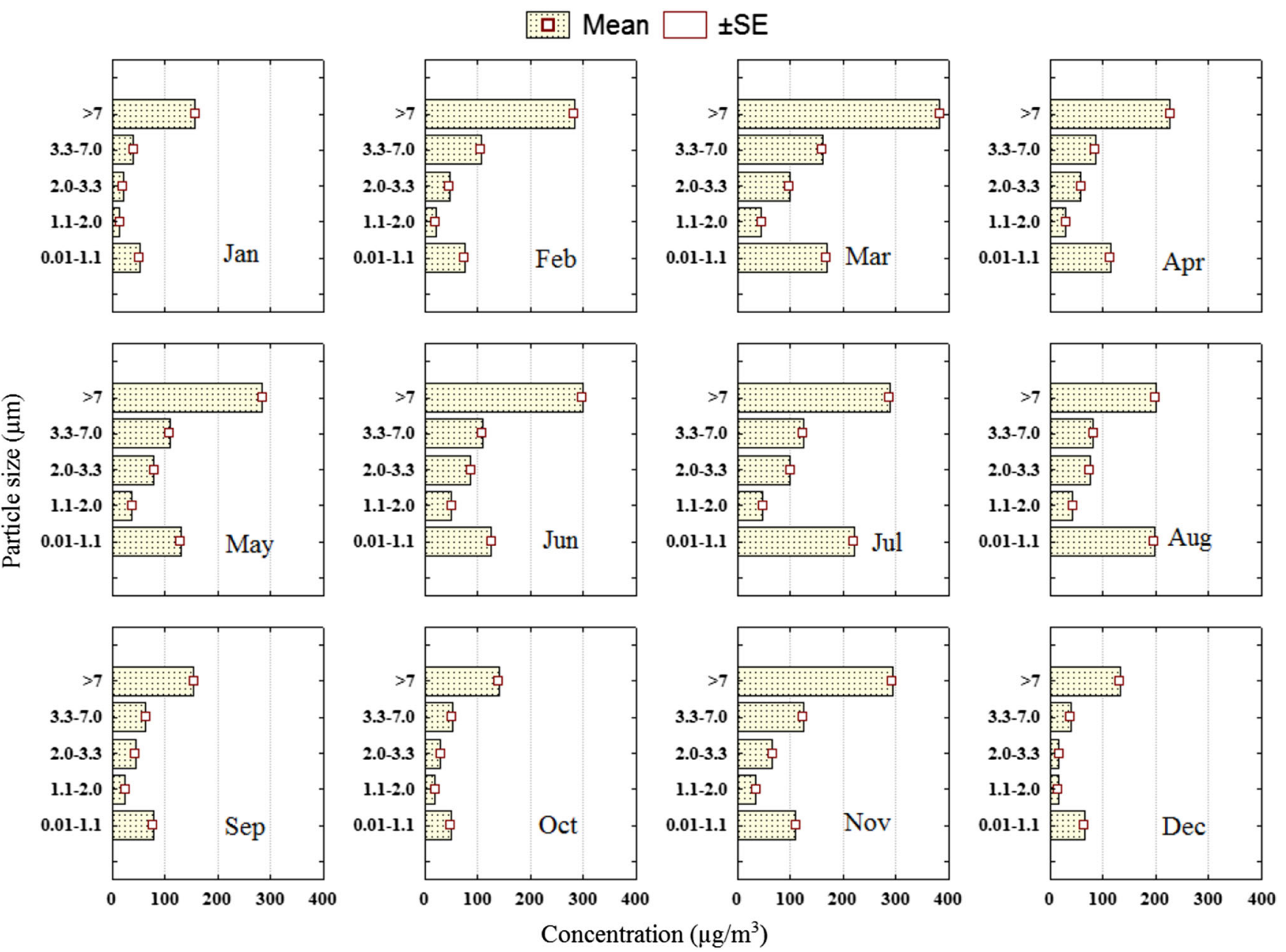

Fig. 6 Temporal variations in monthly average particle size distributions in dust fall

Table 3 Descriptive statistics of dust fall size concentration distribution, $\mu \mathrm{g} \mathrm{m}^{-3}$

\begin{tabular}{lrrrll}
\hline Particle size $(\mu \mathrm{m})$ & \multicolumn{1}{c}{ Mean } & \multicolumn{1}{c}{ Min. } & Max. & SD & CV \\
\hline $0.01-1.1$ & 115.20 & 48.63 & 219.77 & 53.8 & 0.49 \\
$1.1-2.0$ & 31.62 & 13.85 & 50.93 & 12.63 & 0.42 \\
$2.0-3.3$ & 59.77 & 16.09 & 99.30 & 27.78 & 0.49 \\
$3.3-7.0$ & 91.04 & 37.99 & 160.58 & 36.31 & 0.42 \\
$>7$ & 236.43 & 131.75 & 382.36 & 76.50 & 0.34 \\
\hline
\end{tabular}

2003), and Pittsburgh (Stanier et al. 2004). Particle number concentrations were found to be strongly influenced by the traffic density in the urban area (Tuch et al. 2003; Wehner and Wiedensohler 2003; Hussein et al. 2004; Stanier et al. 2004). Sheng and Tang (2013) evaluated the risk of exposure to traffic-related air pollutants for the World Heritage Monuments in the historic center of Macao. The air quality was the worst at evening peak hours with north wind direction sector $\left(0^{\circ}-20^{\circ}\right)$. Wind speed is also has vital role in particle size distribution. The size of particle moved by the wind depends on the size of the particle and the
Table 4 Correlation matrices for selected metrological parameters and dust particle size distribution

\begin{tabular}{lcrrrc}
\hline Parameters & \multicolumn{5}{l}{ Particle size $(\mu \mathrm{m})$} \\
\cline { 2 - 6 } & $0.01-1.1$ & $1.1-2.0$ & $2.0-3.3$ & $3.3-7.0$ & $>7$ \\
\hline $\begin{array}{l}\text { Wind speed } \\
\left(\mathrm{m} \mathrm{s}^{-1}\right)\end{array}$ & $\mathbf{0 . 8 2}$ & $\mathbf{0 . 6 6}$ & $\mathbf{0 . 7}$ & 0.45 & 0.4 \\
Temperature $\left({ }^{\circ} \mathrm{C}\right)$ & $\mathbf{0 . 6}$ & $\mathbf{0 . 6 5}$ & $\mathbf{0 . 5 7}$ & 0.21 & 0.1 \\
RH $(\%)$ & $\mathbf{- 0 . 6 5}$ & $\mathbf{- 0 . 7 5}$ & $\mathbf{- 0 . 7 1}$ & -0.4 & -0.33 \\
\hline
\end{tabular}

Values denote Spearman's coefficient of correlation $(R)$. Significant correlation $(p<0.05)$ is bolded

speed of the wind; larger particles are slowly moved by wind compared with small ones. Large particles also tend to settle to the ground by gravity in a matter of hours.

\section{Conclusion}

In this study, the seasonal variations in falling dust, as well as its chemical and physical constituents, were thoroughly investigated during the entire year of 2009 in Shuwaikh city, Kuwait. 
Representative monthly dust samples were collected and studied in the laboratory. Dust fractions, in both water-soluble and waterinsoluble matter, were identified, and it was found that waterinsoluble matter constituents the major fraction of the total annual dust. ANOVAs showed significant seasonal variation in the concentration of dust fall over the months $(p<0.05)$. Maximum dust deposits were observed between June and August and ranged from 76.4 to $97.6 \pm 2.5$ ton $\mathrm{km}^{-2}$ month ${ }^{-1}$, where dusty winds and low humidity are a common attribute in such arid areas. Major soluble matter species measured were nitrate, sulfate, and chloride, and sulfate was found to be the most abundant inorganic species,averaging $2.37 \pm 0.2$ ton $\mathrm{km}^{-2}$ month $^{-1}$. Major insoluble matter species measured were ash, silica, combustible, and tarry. Ash, silica, and combustible accounted for 63,19 , and $17.8 \%$ of total insoluble dust, and 58.4, 17.7, and $16.6 \%$ of total dust, respectively. Dust particle size $>7 \mu \mathrm{m}$ represented the highest concentration of falling dust. Both chemical characteristics and size distributions of falling dust were influenced by metrological conditions.

Acknowledgments The author would like to thank Kuwait University and KUEPA for dust characterization and continuous support through the course of study.

\section{References}

Baik NJ, Kim YP, Moon KC (1996) Visibility study in Seoul, 1993. Atmos Environ 30:2319-2328

Begum B, Kim E, Biswas SK, Hopke PK (2004) Investigation of sources of atmospheric aerosol at urban and semi-urban areas in Bangladesh. Atmos Environ 38:3025-3038

Canagaratna M, Jayne J, Ghertner D, Herndon S, Shi Q, Jimenez J, Silva P, Williams P, Lanni T, Drewnick F, Demerjian K, Kolb C, Worsnop D (2004) Chase studies of particulate emissions from in-use New York city vehicles. Aerosol Sci Technol 38:555-573

Charlson RJ, Schwartz SE, Hales JM, Cess RD, Coakley JA, Hansen JE, Hofmann DJ (1992) Climate forcing by anthropogenic aerosols. Science 255:423-430

Chate DM, Pranesha TS (2004) Field studies of scavenging of aerosols by rain events. J Aerosol Sci 35:695-706

Chou CCK, Chen TK, Huang SH, Liu SC (2003) Radiative absorption capability of Asian dust with black carbon contamination. Geophys Res Lett 30:1616

Chung Y, Kim H, Dulam J, Harris J (2003) On heavy dust fall observed with explosive sandstorms in Chongwon-Chongju, Korea in 2002. Atmos Environ 37:3425-3433

Crabtree GW (2005) Dust fall on the southern high plains of Texas: Faculty of Texas Tech University in partial fulfillment of the requirements for the Degree of Master of Science

Dentener F (1996) Role of mineral aerosol as a reactive surface in the global troposphere. J Geophys Res 101(D17):22869-22890

Eriksson E (1959) The yearly circulation of chlorine and sulfur in nature: meteorological, geochemical and pedological implications. Tellus 11:375-403

Fan X, Okada K, Niimura N, Kai K, Arao K, Shi G, Qin Y, Mitsuta Y (1996) Mineral particles collected in China and Japan during the same Asian dust-storm event. Atmos Environ 30:347-351

Fenter FF, Caloz F, Rossi MJ (1995) Experimental evidences for the efficient "dry deposition" of nitric acid on calcite. Atmos Environ 29:3365-3372
Fruin S, Winer A, Rodes C (2004) Black carbon concentrations in California vehicles and estimation of in-vehicle diesel exhaust particulate matter exposures. Atmos Environ 38(25):4123-4133

Gao Y, Arimoto R, Duce RA, Zhang XY, Zhang GY, An ZS, Chen LQ, Zhou MY, Gu DY (1997) Temporal and spatial distribution of dust and its deposition to the China Sea. Tellus B 49:172-189

Gwilliam K, Kojima M, Johnson T (2004) Reducing air pollution from urban transport. The World Bank, Washington, DC

Harrison RM, Jones M, Collins G (1999) Measurements of the physical properties of particles in the urban atmosphere. Atmos Environ 33:309-321

Hien PD, Binh NT, Truong Y, Ngo NT, Sieu LN (2001) Comparative receptor modeling study of TSP, PM2 and PM10 in Ho Chi Minh City. Atmos Environ 35:2669-2678

Hien PD, Bac VT, Lam DT, Thinh NTHT (2004) PMF receptor modeling of fine and coarse PM10 in air masses governing monsoon conditions in Hanoi, northern Vietnam. Atmos Environ 38:189-201

Hoffmann MR (1986) On the kinetics and mechanism of oxidation of aquated sulfur dioxide by ozone. Atmos Environ 20:1145-1154

Hussein T, Puustinen A, Aalto PP, Mäkelä JM, Hämeri K, Kulmala M (2004) Urban aerosol number size distributions. Atmos Chem Phys 4:391-411

Iwasaka Y, Shi G, Shen Z, Kim Y, Trochkine D, Matsuki A, Zhang D, Shibata T, Nagatani M, Nakata H (2003) Nature of atmospheric aerosols over the desert areas in the Asian continent: chemical state and number concentration of particles measured at Dunhuang, China. Water Air Soil Pollut Focus 3(2):129-145

Johansson LS, Tullin C, Leckner B, Sjovall P (2003) Particle emissions from biomass combustion in small combustors. Biomass Bioenergy 25(12):435-446

Krueger BJ, Grassian VH, Cowin JP, Laskin A (2004) Heterogeneous chemistry of individual mineral dust particles from different dust source regions: the importance of particle mineralogy. Atmos Environ 38:6253-6261

Latif M, Rozali M (1991) Dust fall at air Keroh (Melaka) and Teluk Kalung (Terengganu) industrial areas. Malays J Anal Sci 5:137-146

Li W, Shao L (2009) Observation of nitrate coatings on atmospheric mineral dust particles. Atmos Chem Phys 9(6):1863-1871

Li X, Guo X, Liu X, Liu C, Zhang S, Wang Y (2009) Distribution and sources of solvent extractable organic compounds in PM2.5 during 2007 Chinese Spring Festival in Beijing. J Environ Sci 21(2):142-149

Li W, Zhang D, Shao L, Zhou S, Wang W (2011) Individual particle analysis of aerosols collected under haze and non-haze conditions at a high-elevation mountain site in the North China plain. Atmos Chem Phys 11(22):11733-11744

Lighty JS, Veranth JM, Sarofim AF (2000) Combustion aerosols: factors governing their size and composition and implications to human health. J Air Waste Manag Assoc 50:1565-1618

Liu LY, Brauning A, Zhand Z, Dong Z, Esper J (2004) Dust fall in China's western loess plateau as influenced by dust storm and haze events. Atmos Environ 38:1699-1703

Lodge JP Jr (1988) Methods of air sampling and analysis, 3rd edn. CRC Press, Boca Raton, FL, pp 440-443

Lyons TJ, Scott WD (1990) Principles of air pollution meteorology. Belhaven Press, London

Martin LR (1984) Kinetic studies of sulfite oxidation in aqueous solution, $\mathrm{SO}_{2}, \mathrm{NO}, \mathrm{NO}_{2}$ oxidation mechanisms. In: Calvert JG (ed) Atmospheric considerations. Butterworth Press, Boston, pp 63-100

Maxwell-Meier K, Weber R, Song C, Orsini D, Ma Y, Carmichael GR, Streets DG (2004) Inorganic composition of fine particles in mixed mineral dust-pollution plumes observed from airborne measurements during ACE-Asia. J Geophys Res 109:D19S07

McArdle JV, Hoffmann MR (1983) Kinetics and mechanism of the oxidation of aquated sulfur dioxide by hydrogen peroxide at low pH. J Phys Chem 87:5425-5429 
McInnes LM, Covert DS, Quinn PK, Germani MS (1994) Measurements of chloride depletion and sulfur enrichment in individual sea-salt particles collected from the remote marine boundary layer. J Geophys Res 99:8257-8268

Mirme A, Ruuskanen J (1996) Comparison of aerosol measurements in urban environment. Aerosol Sci Technol 27:S23-S24

Modaihsh AS (1997) Characteristics and composition of the falling dust sediments on Riyadh city, Saudi Arabia. J Arid Environ 36:211-223

Nicholson KW (1988) The dry deposition of small particles: a review of experimental measurements. Atmos Environ 22:2653-2666

Niemi JV, Tervahattu H, Vehkamäki H, Kulmala M, Koskentalo T, Sillanpää M, Rantamäki M (2004) Characterization and source identification of a fine particle episode in Finland. Atmos Environ 38:5003-5012

Nishikawa M, Kanamori S, Kanamori N, Mizoguchi T (1991) Kosa aerosol as eolian carrier of anthropogenic material. Sci Total Environ 107:13-27

Naddafi K, Nabizadeh R, Soltanianzadeh Z, Ehrampoosh MH (2006) Evaluation of dustfall in the air of Yazd. Iran J Environ Health Sci Eng 3(3):161-168

Norela S, Nurfatiha M, Maimon A, Ismail B (2009) Wet deposition in the residential area of the Nilai Industrial Park in Negeri Sembilan, Malaysia. World Appl Sci J 7:170-179

Ntziachristos L, Samaras Z, Eggleston S, Goriben N, Hassel D, Hickman A, Joumard R, Rijkeboer R, White L, Zierock K (2000) COPERT III computer programme to calculate emissions from road transport: methodology and emission factors (version 2.1). In: Technical report prepared by the European Environment Agency, Copenhagen, Report 49. http://reports.eea.europa.eu/ Technical_report_No_49/en/tech49.pdf

Offer ZY, Goossen D (2001) Ten years of Aeolian dust dynamics in a desert region (Negev desert, Israel): analysis of airborne dust events. J Arid Environ 47(2):211-249

Okada K, Naruse H, Tanaka T, Nemoto O, Iwasaka Y, Wu P, Ono A, Duce R, Uematsu M, Merrill J (1990) X-ray spectrometry of individual Asian dust-storm particles over the Japanese islands and the North Pacific Ocean. Atmos Environ 24:1369-1378

Pandey SK, Tripathi BD, Mishra VK (2008) Dust deposition in a sub-tropical opencast coalmine area, India. J Environ Manag 86(1):132-138

Parungo F, Kim Y, Zhu C, Harris J, Schnell R, Li X, Yang D, Fang X, Yan P, Yu X Zhou M, Chen Z, Qian F, Park K (1996) Asian dust storms and their effects on radiation and climate. Part II. STC Technical Report 2959, pp 34

Penttinen P, Timonen KL, Tiittanen P, Mirme A, Ruuskanen J, Pekkanen J (2001) Number concentration and size of particles in urban air: effects on spirometric lung function in adult asthmatic subjects. Environ Health Perspect 109:319-323

Peters A, Wichmann HE, Tuch T, Heinrich J, Heyder J (1997) Respiratory effects are associated with the number of ultrafine particles. Am J Respir Crit Care Med 155:1376-1383

Pope CA (2000) Review: epidemiological basis for particulate air pollution health standards. Aerosol Sci Technol 32:4-14

Quan H (1995) Dust transport and modification. Doctoral degree dissertation of Saitama University, Saitama, pp 49-90

Reheis MC, Kihl R (1995) Dust deposition in Southern Nevada and California, 1984-1989: relations to climate, source area and source lithology. J Geophys Res 100:8893-8918

Samet JM, Dominici F, Curriero FC, Coursac I, Zeger SL (2000) Fine particulate air pollution and mortality in 20 US Cities, 1987-1994. N Engl J Med 343:1742-1749

Seinfeld JH (1986) Atmospheric chemistry and physics of air pollution. Wiley, New York, p 738

Sheng N, Tang U (2013) Risk assessment of traffic-related air pollution in a world heritage city. Int J Environ Sci Technol 10:11-18

Shi JP, Harrison RM (1999) Investigation of ultrafine particle formation during diesel exhaust dilution. Environ Sci Technol 33:3730-3736
Stanier CO, Khlystov AY, Pandis SN (2004) Ambient aerosol size distributions and number concentrations measured during the Pittsburgh Air Quality Study (PAQS). Atmos Environ 38:3275-3284

Ta W, Xiao H, Qu J, Xiao Z, Yang G, Wang T, Zhang X (2004) Measurements of dust deposition in Gansu Province, China, 1986-2000. Geomorphology 57:41-51

Tang Y (2004) Three-dimensional simulations of inorganic aerosol distributions in East Asia during spring 2001. J Geophys Res 109:D19S2

Tang UW, Wang ZS (2006) Determining gaseous emission factors and driver's particle exposures during traffic congestion by vehicle-following measurement techniques. J Air Waste Manag Assoc 56:1532-1539

Tang UW, Wang ZS (2007) Influences of urban forms on trafficinduced noise and air pollution: Results from a modelling system. Environ Model Softw 22:1750-1764

Tiitta P, Raunemaa T, Tissari J, Yli-Tuomi T, Leskinen A, Kukkonen J, Harkonen J, Karppinen A (2002) Measurements and modeling of PM2.5 concentrations near a major road in Kuopio, Finland. Atmos Environ 36:4057-4068

Tripathi BD, Tripathi A, Mishra K (1991) Atmospheric dust fall deposits in Varanasi city. Atmos Environ B 25(1):109-112

Tuch TM, Wehner B, Pitz M, Cyrys J, Heinrich J, Kreyling WG, Wichmann HE, Wiedensohler A (2003) Long-term measurements of size-segregated ambient aerosol in two German cities located $100 \mathrm{~km}$ apart. Atmos Environ 37:4687-4700

Väkevä M, Hämeri K, Puhakka T, Nilsson ED, Hohti H, Mäkelä JM (2000) Effects of meteorological processes on aerosol particle size distribution in an urban background area. J Geophys Res Atmos 105:9807-9821

Wang Y, Zhuang G, Sun Y, An Z (2005) Water-soluble part of the aerosol in the dust storm season-evidence of the mixing between mineral and pollution aerosols. Atmos Environ 39:7020-7029

Wehner B, Wiedensohler A (2003) Long term measurements of submicrometer urban aerosols: statistical analysis for correlations with meteorological conditions and trace gases. Atmos Chem Phys 3:867-879

Woo KS, Chen DR, Pui DYH, McMurry PH (2001) Measurement of Atlanta aerosol size distributions: observations of ultrafine particle events. Aerosol Sci Technol 34:75-87

Yadav S, Rajamani V (2006) Air quality and trace metal chemistry of different size fractions of aerosols in N-NW India-implications for source diversity. Atmos Environ 40(4):698-712

Yang D, Ji X, Xu X, Fu J, Wen Y (1991) An analysis of a sandstorm weather. Acta Meteorologica Sinica 49:334-342 (in Chinese)

Yang CY, Chen YS, Chiu HF, Goggins WB (2005) Effects of Asian dust storm events on daily stroke admissions in Taipei, Taiwan. Environ Res 99:79-84

Zhang D (1996) Features of nitrate-containing particles in urban atmosphere over Beijing. Scientia Atmospherica Sinica 20:408-415

Zhang X, Gong S, Shen Z, Mei F, Xi X, Liu L, Zhou Z, Wang D, Wang Y, Cheng Y (2003) Characterization of soil dust aerosol in China and its transport and distribution during 2001 ACE-Asia: 1. Network observations. J Geophys Res 108:4261-4274

Zheng M, Wana TSM, Fang M, Wang F (1997) Characterization of the nonvolatile organic compounds in the aerosols of Hong Kongidentification, abundance and origin. Atmos Environ 31(2):227-237

Zhou M, Chen Z, Huang R, Wang Q, Arimoto R, Parungo F, Lenschow D, Okada K, Wu P (1994) Effects of two dust storms on solar radiation in the Beijing-Tianjin area. Geophys Res Lett 21:2697-2700

Zhuang H, Chan CK (1997) Size distribution of inorganic aerosols at a coastal site. J Aerosol Sci 28:S213-S214

Ziomas IC, Melas D, Zerefos ChS, Bais AF (1995) Forecasting peak pollutant levels from meteorological variables. Atmos Environ 29:3703-3711 